\title{
DETEKSI DINI PENYAKIT DEGENERATIF PADA LANSIA DENGAN PEMERIKSAAN TEKANAN DARAH, GLUKOSA DARAH DAN ASAM URAT
}

\author{
Rita afni, SST, M.Kes ${ }^{(1)}$, Ani Triana, SST, M.Kes ${ }^{(2)}$ \\ ${ }^{(1),(2)}$ STIKes Hang Tuah Pekanbaru \\ Email: rita.afni@htp.ac.id
}

\begin{abstract}
ABSTRAK
The aging process is a life cycle characterized by the stages of decreasing various functions of the body's organs, with the body becoming more susceptible to various diseases that can cause death, for example in the cardiovascular system and blood vessels, respiratory, digestive, endocrine and so on. Degenerative disease is a health condition in which an organ or related tissue continues to decline over time. This disease occurs due to changes in body cells that ultimately affect the overall organ function. At RT 03 RW 01 Maharani Village, Rumbai District, there are many problems in the elderly who lack knowledge of degenerative diseases in the elderly and the elderly posyandu activities are not running, therefore we carry out examinations on the elderly at RT 03 RW 01 Maharani Village Kec. Tassel. Prevent degenerative diseases in the elderly by checking blood pressure, blood sugar and uric acid. Conducting education activities to increase knowledge about degenerative diseases in the elderly and their prevention. It has been seen that mothers have a significant role in this activity, which is evident at the time of the implementation of this activity there were 23 elderly people who attended and helped carry out this activity. The results of this activity were obtained by the elderly to understand and understand about early detection and the importance of early detection of degenerative diseases in the elderly, in everyday life and to know how their health condition is.
\end{abstract}

Keywords: Early Detection, Degenarative Diseases, Elderly

\begin{abstract}
ABSTRAK
Proses penuaan adalah siklus kehidupan yang ditandai dengan tahapan menurunnya berbagai fungsi organ tubuh, dengan semakin rentannya tubuh terhadap berbagai serangan penyakit yang dapatmenyebabkan kematian misalnya pada sistem kardiovaskuler danpembuluh darah, pernafasan, pencernaan, endokrin dan lain sebagainya. Penyakit degeneratif adalah kondisi kesehatan di mana organ atau jaringan terkait keadaannya yang terus menurun seiring waktu.Penyakit ini terjadi karena adanya perubahan pada sel-sel tubuh yang akhirnya memengaruhi fungsi organ secara menyeluruh. Di RT 03 RW 01 Kelurahan Maharani Kecamatan Rumbai terdapat banyak masalah pada lansia yang kurangan pengetahuan tentang penyakit degeneratif pada lansia dan kurang berjalannya kegiatan posyandu lansia, oleh karena itu kami melakukan pemeriksaan pada lansia di RT 03 RW 01 Kelurahan Maharani Kec. Rumbai. Melakukan pencegahan penyakit degeneratif pada lansia dengan pemeriksaan Tekanan darah, Gula darah dan Asam urat. Melakukan kegiatan penyuluhan untuk dapat meningkatkan pengetahuan tentang penyakit degeneratif pada lansia beserta pencegahannya. sudah terlihat bahwa ibu ibu cukup berperan dalam kegiatan ini yaitu terbukti pada saat pelaksanaan kegiatan tersebut ada 23 lansia yang hadir dan membantu pelaksanaan kegiatan ini. Hasil kegiatan ini didapatkan para lansia memahami dan mengerti tentang deteksi dini dan pentingnya deteksi dini penyakit degeneratif pada lansia, dalam kehidupan sehari hari dan mengetahui bagaimana keadaan kesehatannya.
\end{abstract}

Kata Kunci: Deteksi Dini, Penyakit Degenaratif, Lansia 


\section{PENDAHULUAN}

Menurut World Health Organisation (WHO), lansia adalah seseorang yang telah memasuki usia 60 tahun keatas. Lansia merupakan kelompok umur pada manusia yang telah memasuki tahapan akhir dari fase kehidupannya. Kelompok yang dikategorikan lansia ini akan terjadi suatuproses yang disebut Aging Process atau proses penuaan.

Proses penuaan adalah siklus kehidupan yang ditandai dengan tahapantahapan menurunnya berbagai fungsi organ tubuh, yang ditandai dengansemakin rentannya tubuh terhadap berbagai serangan penyakit yang dapatmenyebabkan kematian misalnya pada sistem kardiovaskuler danpembuluh darah, pernafasan, pencernaan, endokrin dan lain sebagainya.Hal tersebut disebabkan seiring meningkatnya usia sehingga terjadiperubahan dalam struktur dan fungsi sel, jaringan, serta sistem organ.Perubahan tersebut pada umumnya mengaruh pada kemundurankesehatan fisik dan psikis yang pada akhirnya akan berpengaruh padaekonomi dan sosial lansia. Sehingga secara umum akan berpengaruh pada activity of daily living (Kurniali, 2013).

Penyakit degeneratif adalah kondisi kesehatan di mana organ atau jaringan terkait keadaannya yang terus menurun seiring waktu.Penyakit ini terjadi karena adanya perubahan pada sel-sel tubuh yang akhirnya memengaruhi fungsi organ secara menyeluruh. Proses penuaan adalah penyebab penyakit degeneratif yang paling umum. semakin bertambah usia, maka fungsi jaringan dan organ tubuh pun akan semakin mengalami penurunan. Itu sebabnya, orang lanjut usia (lansia) lebih mungkin mengalami berbagai jenis penyakit degeneratif dibandingkan dengan orang yang lebih muda.

\section{METODE KEGIATAN}

Metode pengabdian masyarakat ini dilaksanakan dalam bentuk penyuluhan dengan mengangkat tema “ Deteksi Dini penyakit degenerative pada lansia dengan pemeriksaan tekanan darah, asam urat dan glukosa " dengan memberikan ceramah langsung dan leafleat berisi materi dan gambar yang menarik serta Tanya jawab seputar penyakit degenerative pada lansia. Dan Melakukan pemeriksaan kesehatan pada lansia meliputi pemeriksaan tekanan darah, denyut nadi, pernafasan, glukosa darah, dan asam urat. 


\section{HASIL DAN PEMBAHASAN}

\section{Hasil Pelaksanaan}

Kegiatan yang dilakukan dalam pengabdian kepada masyarakat ini dilaksanakan dalam beberapa tahapan yang diawali dengan pemberian penyuluhan terlebih dahulu tentang deteksi dini penyakit degeneratif pada lansia dengan pemeriksaan tekanan darah, glukosa darah dan asam urat.

Kegiatan penyuluhan dan pemeriksaan pada lansia ini telah dilkasanakan pada hari rabu tanggal 27 November 2019 bertempat di Kelurahan Maharani Kecamatan Rumbai. Kegiatan pengabdian masyarakat ini memberikan hasil sebagai berikut:

1. Tenaga Kesehatan

Berdasarkan hasil pelaksanaan Sosialisasi Deteksi Dini Penyakit Degeneratif pada lansia di Kelurahan Maharani Kecamatan Rumbai, sudah terlihat bahwa peserta cukup berperan dalam kegiatan ini yaitu terbukti 25 lansia yang hadir dan hadir dan membantu pelaksanaan kegiatan ini
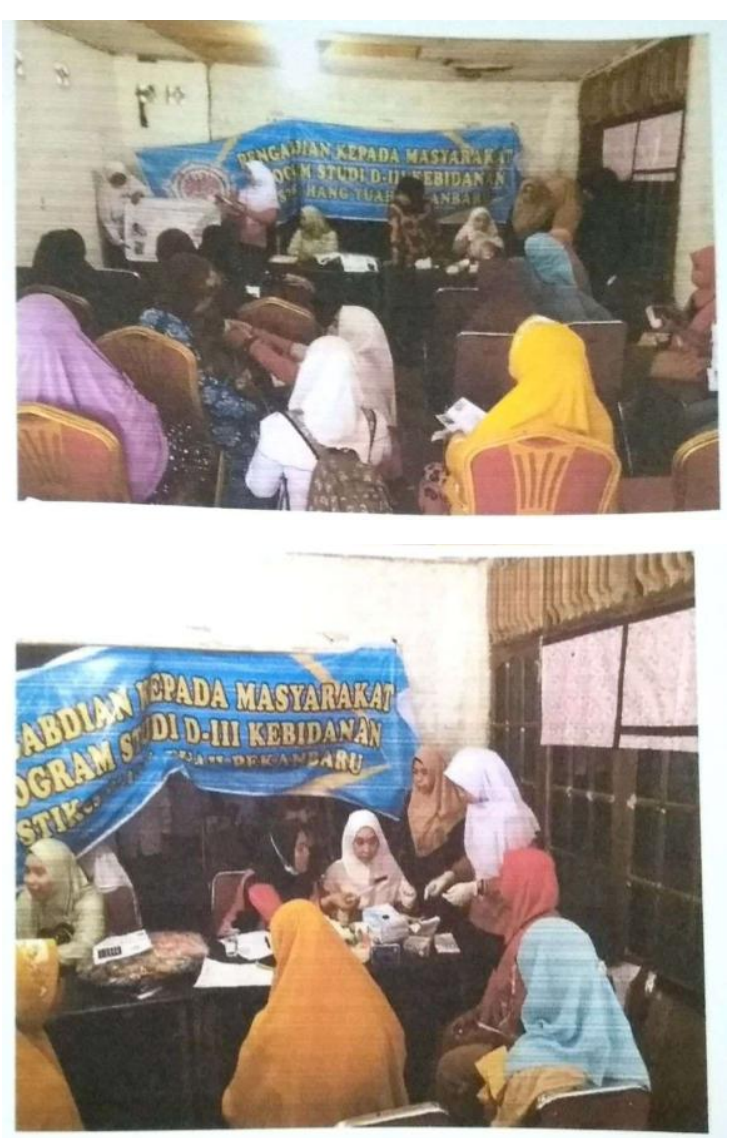

2. Para Lansia

a. Para lansia memahami dan mengerti tentang deteksi dini penyakit degenerative pada lansia

b. Para lansia sudah mengerti bahwa deteksi dini penyakit degenerative pada lansia itu sangat penting dalam kehidupan sehari hari

c. Para lansia mengetahui bagaimana keadaan

kesehatannya

\section{Pembahasan}

Kegiatan penyuluhan tentang

Deteksi Dini Penyakit Degeneratif 
pada lansia di Kelurahan Maharani Kecamatan Rumbai berjalan dengan sangat baik. Hal ini terlihat dari antusias nya para lansia yang hadir pada saat kegiatan berlangsung banyak para lansia bertanya menunjukkan rasa ingin tahu mereka terhadap materi yang disampaikan. Selama ini, penegetahuan lansia tentang deteksi dini penyakit degenerative adalah masalah yang biasa baginya, tetapi setelah mendengarkan penyuluhan ini para lansia mengerti pentingnya mengetahui deteksi dini penyakit degenerative pada lansia dalam kehidupan sehari-hari.

Lansia sehat adalah lansia yang mampu menyesuaikan diri terhadap perubahan fisik mereka dan lingkungan sosialnya. Deteksi dini penyakit degenerative pada lansia adalah upaya memberdayakana anggota rumah tangga agar sadar, mau serta mampu melakukan deteksi dini penyakit degenerative. Dari hasil pemeriksaan tekanan darah, denyut nadi, pernafasan, glukosa dan asam urat, maka lansia mengetahui bagaimana keadaan kesehatannya.

\section{KESIMPULAN}

Dari kegiatan pengabdian masyarakat sampai saat ini dapat disimpulkan bahwa hasil pemeriksaan pada lansia di RW 01 RT 03 Kelurahan Maharani terdapat beberapa lansia yang memiliki penyakit degenerative.

\section{DAFTAR PUSTAKA}

Kurniali, Petter C. 2013. Hidup Bersama Diabetes. Jakarta : PT Elex Media Komputindo.

Kushariyadi.2011. Asuhan Keperawatan pada Klien Lanjut Usia. Jakarta : Salemba Medika.

Mujahidullah, $\quad$ Khalid. 2012. Keperawatan Beriatrik. Yogyakarta : Pustaka Pelajar.

Nugroho, H Wahyudi. 2008. Keperawatan Gerontik \& Geriatrik Edisi 3.Jakarta : Buku Kedokteran EGC.

Padila.2013. Keperawatan Gerontik.Yogyakarta : Nuha Medika.

Pudiastuti, Ratna Dewi. 2013. Penyakitpenyakit Mematikan. Yogyakarta : Nuha Medika.

Tamber, S dan Noorkasiani. 2011. Kesehatan Usia Lanjut dengan Pendekatan Asuhan Keperawatan. Jakarta : Salemba Medika. 